Library, E-01 Admin. Bldg.

$$
\text { (5) } 11969
$$

BUILDING SCIENCE SERIES 23

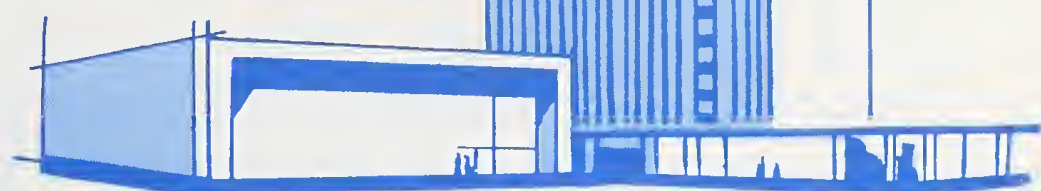

Hail Resistance of Roofing Products

U.S. DEPARTMENT OF COMMERCE National Bureau of Standards 


\section{Announcing-The Building Science Series}

The "Building Science Series" disseminates technical information developed at the Bureau on building ma. terials, components, systems, and whole structures. The series presents research results, test methods, and performance criteria related to the structural and environmental functions and the durability and safety characteristics of building elements and systems.

These publications, similar in style and content to the NBS Building Materials and Structure Reports (193859 ), are directed toward the manufacturing, design, and construction segments of the building industry, standards organizations, officials responsible for building codes, and scientists and engineers concerned with the properties of building materials.

The material for this series originates principally in the Building Research Division of the NBS Institute for Applied Technology. Published or in preparation are:

BSS1. Building Research at the National Bureau of Standard. (In preparation.)

BSS2. Interrelations Between Cement and Concrete Properties: Part 1, Materials and Techniques, Water Requirements and Trace Elements. 35 cents

BSS3. Doors as Barriers to Fire and Smoke. 15 cents

BSS4. Weather Resistance of Porcelain Enamels: Effect of Exposure Site and other Variables After Seven Years. 20 cents

BSS5. Interrelations Between Cement and Concrete Properties: Part 2, Sulfate Expansion, Heat of Hydration, and Autoclave Expansion. 35 cents

BSS6. Some Properties of the Calcium Aluminoferrite Hydrates. 20 cents

BSS7. Organic Coatings. Properties, Selection, and Use. $\$ 2.50$

BSS8. Interrelations Between Cement and Concrete Properties: Part 3, Compressive Strengths of Portland Cement Test Mortars and Steam-Cured Mortars. 55 cents

BSS9. Thermal-Shock Resistance for Built-Up Membranes. 20 cents

BSS10. Field Burnout Tests of Apartment Dwelling Units. 25 cents

BSS11. Fire Resistance of Steel Deck Floor Assemblies. 25 cents

BSS12. Performance of Square-Edged Orifices and Orifice-Target Combinations as Air Mixers. 15 cents

BSS13. Shrinkage and Creep in Prestressed Concrete. 15 cents

BSS14. Experimental Determination of Eccentricity of Floor Loads Applied to a Bearing Wall. 15 cents

BSS15. Interrelations Between Cement and Concrete Properties: Part 4, Shrinkage of Hardened Portland Cement Pastes. 75 cents

BSS16. Techniques for the Survey and Evaluation of Live Floor Loads and Fire Loads in Modern Office Buildings. 40 cents

BSS17. Causes of Variation in Chemical Analyses and Physical Tests of Portland Cement. 40 cents

BSS18. Smoke and Gases Produced by Burning Aircraft Interior Materials. 35 cents

BSS19. A Study of the Variables Involved in the Saturating of Roofing Felts. (In press)

BSS20. Performance of Buildings-Concept and Measurement. Man and His Shelter. (In preparation)

BSS21. Algorithms for Psychrometric Calculations. (In preparation)

BSS22. Investigation of Performance Characteristics for Sanitary Plumbing Fixtures. (In preparation)

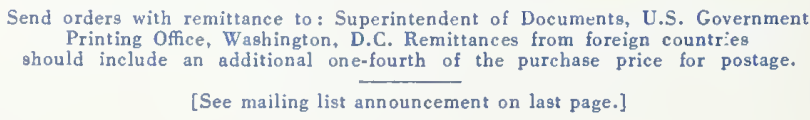


UNITED STATES DEPARTMENT OF COMMERCE - Maurice H. Stans, Secretary NATIONAL BUREAU OF STANDARDS • A. V. Astin, Director

\title{
Hail Resistance of Roofing Products
}

\author{
Sidney H. Greenfeld \\ Research Associate \\ Asphalt Roofing Manufacturers Association* \\ *(Formerly Asphalt Roofing Industry Bureau) \\ Building Research Division \\ Institute for Applied Technology \\ National Bureau of Standards \\ Washington, D. C. 20234
}

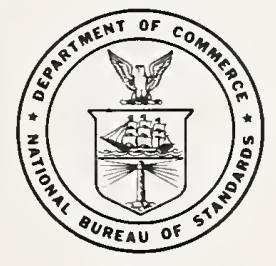

Nat. Bur. Stand. (U.S.), Bldg. Sci. Ser. 23, 11 pages (August 1969) CODEN: BSSNB

Issued August 1969

For sale by the Superintendent of Documents, U.S. Government Printing Office Washington, D.C. 20402-Price 25 cents 



\section{Contents}

2. Apparatus -.-_- 3

2.1. Test apparatus -_- 3

2.2. Hailstone carriers _.

2.3. Hailstone molds

2.4. Specimen construction -_- 4

3. Procedures --

3.1. Shooting hailstones at roofing -

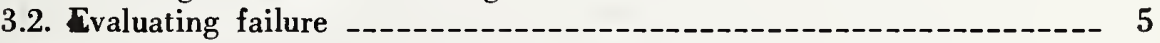

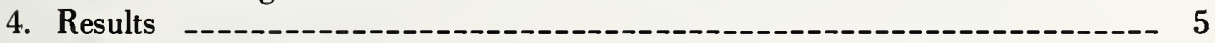

4.1. Asphalt shingles

4.2. Built-up roofs -_- 7

4.3. Nonbituminous roofing -_. 8

5. Conclusions -

6. References - 



\title{
Hail Resistance of Roofing Products
}

\section{Sidney H. Greenfeld}

\begin{abstract}
A test was developed for evaluating the hail resistance of roofings, in which synthetic hail. stones (ice spheres) of various sizes were shot at roof assemblies at their free-fall terminal velocities. Indentations, granule loss and roofing fracture were observed. The following conclusions have been made from these results:

(a) All roofing materials have some resistance to hail damage, but as the size of the hail increases, a level of impact energy is reached at which damage occurs. This level lies in the range of $1 \frac{1}{2}$ to 2 inch $(3.8-5.1 \mathrm{~cm})$ hailstones for most prepared roofings.

(b) Because of the ways in which prepared roofings are applied, most products have areas of different vulnerability.

(c) The solidly supported areas of roofing tend to be the most resistant to hail damage.

(d) Heavier shingles tend to be more hail-resistant than Type 235 shingles.

(e) Weathering tends to lower the hail resistance of asphalt shingles.

(f) Built-up roofs on dense substrates tend to resist hail better than those on soft substrates.

(g) Built-up roofs made with inorganic felts tend to be more hail resistant than those made with organic felts.

(h) Coarse aggregate surfacing tends to increase the hail resistance of roofing.
\end{abstract}

Key words: Asphalt shingles; built-up roofing; hail; roofing; shingles; storm damage.

\section{Introduction}

Hail, as a destructive force of nature, has plagued man, his crops and his property since the very beginnings of civilization. By far the vast majority of hailstorms contain hailstones that are relatively small. These small stones can damage crops, but not roofings. However, every year there are a number of storms in which hailstones occur in the range of $11 / 2$ to 3 in. (3.8 to $7.6 \mathrm{~cm}$ ), or more, in diameter.

In the United States, except on rare occasions, storms containing large hailstones are encountered in the States between the Appalachian and Rocky Mounains. While there is no evidence that the number of such storms has been increasing in recent years, the population has grown in this part of the country, more buildings have been constructed and, consequently, the incidence of building damage has increased.

It has been extremely difficult, for a number of reasons, to determine precisely the damage attributable to hail. The same storm fronts that spawn large hailstones contain high winds, not too infrequently of tornadic velocities. The short hail period is usually followed by torrential rains. Consequently, in the "post-mortem" analysis of building damage caused by a storm, the allocation of the causes cannot always be made. Therefore, the Weather Bureau Reports $[1]^{1}$ usually lump these three causes of damage together, but where possible, have separated them.

The hailstones in a storm are rarely of uni- form size and, consequently, some damage remains hidden and does not appear until months or years later, in another storm, which might not be damaging on its own, or in cold weather, when ice penetration increases the destruction sufficiently to be observable. Even when only the damage unequivocally attributable to hail is considered, hail produces a greater annual loss through building damage than the morespectacular tornado.

It is beyond the scope of this paper to discuss the theories of hail formation and growth, or storm development; this information may be found in references [2-6].

Two types of damaging hailstorms are encountered in the United States [5]. The most prevalent type is known as the frontal storm. It involves the encounter of a cold, high air mass with a low, moist, warm air mass. The cold air tends to fall and the warm, moist air tends to rise, carrying its moisture with it. The moisture cools through heat exchange with the cold air and evaporation as the air expands upward. Eventually it becomes cooled significantly below the freezing point and remains subcooled until it encounters a nucleus upon which to freeze. As more water hits any particular ice particle, the particle grows. Because everything in these upper regions is at a temveloped. It was conceded, following Laurie, that (1) ordinary impact tests were not satis-

${ }^{1}$ Figures in brackets indicate the literature references at the end of this paper. 
perature much below the freezing point of water, the ice that forms does so rapidly and traps air in the process. This forms a milky layer of low-density ice. When an ice particle becomes too heavy to be raised farther by the updraft, it starts to fall. More condensation is collected during the fall, and once it reaches an area with temperatures above the freezing

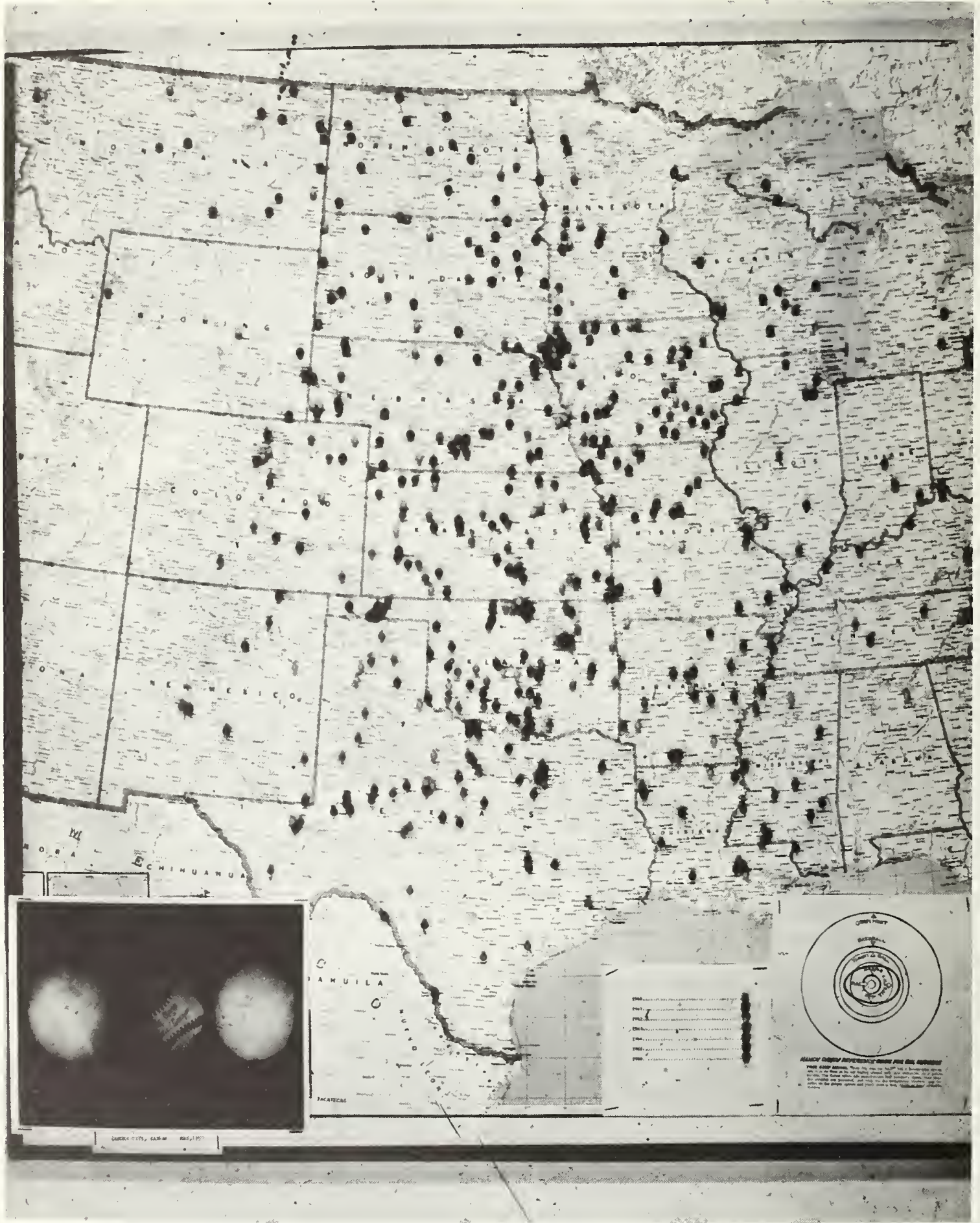

Each pin represents a storm in which at least $\$ 5,000$ worth of building damage was done by hail.

FIGURE 1. Hail storm distribution map. 
point, the condensation on it is liquid water, and air can escape. This forms a layer of clear, high-density ice.

Sooner or later, the particle encounters another strong updraft, starts back up and freezes, subcools and goes through its tumbling cycle over and over again. Thus, the hailstone is found to consist of alternate layers of milky (low density) ice and clear (high density) ice. When the hailstone encounters no updraft sufficient to lift it, it falls to earth, usually at a velocity approximating the free-fall terminal velocity [9].

The second type of storm occurs on the eastern slopes of the Rocky Mountains; thus, it is called an orographic storm. A front of warm, moist air hits the base of the mountains, expands upward until the nucleation, freezing and tumbling processes occur and then the hailstones drop out as in the frontal storm. This type of storm tends to drop its hailstones at about $6000 \mathrm{ft}$.

Figure 1 is a map of the central United States showing the distribution of storms during the years 1960-1966 in which at least $\$ 5000$ worth of building damage was done by hail in each storm. The orographic storms form an imperfect line at the left of the figure; the frontal storms account for the rest of the points. Only infrequently do building-damaging storms occur outside of this area.

Hailstorms occur all over the world in open regions where rapidly moving air masses can develop. However, only meteorological reports on storms and studies on the physics of hail formation can be found in the literature. Oc- casionally reports appear in the trade literature $[7,8]$ on hail damage to buildings, but only one paper has appeared in which a serious effort has been made to evaluate the effects objectively. In this paper [9], J.A.P. Laurie reported that he used $21 / 2$-in $(6.4 \mathrm{~cm})$ artificial hailstones, made by cutting cylindrical cores from blocks of ice, cutting them to heights equal to their diameter and molding them to roughly spherical shape. He fired these missiles at various velocities at building materials with a grenade launcher and determined the threshold energy of damage. The velocities were controlled by the size of the charge in the blank cartridges used in the launcher.

Because of the difficulties in controlling the velocities of the hailstones, an air-operated piston was developed and used as the launcher in the latter part of Laurie's study.

Laurie's paper, being the only one in its field, was the base from which this work was defactory, (2) the use of ice spheres was extremely desirable, if not absolutely necessary, (3) hail usually struck at its approximate freefall termin?l velocity (corroborated by others), and (4) a criterion for failure was damage that would permit the penetration of liquid water to an appreciable extent. However, it was decided to use a less complicated launcher, use "hailstones" of various sizes, cast the "hailstones" to approximate spheres more closely and explore areas of different vulnerability on various roofing systems. The work was primarily directed at bituminous roofing materials, but a sampling of other roofings was made.

\section{Apparatus}

\subsection{Test Apparatus}

The apparatus consisted of a compressed air gun, for launching the hailstones, a timer, for determining their velocity, and a target area, for positioning the specimen to be tested. The physical layout of the apparatus is shown in figure 2.

The apparatus consisted of a specimen (target) area (1), timing range (2), gas gun (3), gas cylinder (4), timer (5), hailstone carrier (6), hailstone molds (7), and a triggering mechanism (8). The roofing specimen to be tested is mounted on a roof deck, just as in service, and clamped in place against the backstop in position (1). The timing range consists of a metal frame of $3 / 4$-in $(1.9 \mathrm{~cm})$ angle iron on which are mounted two microswitches $2.0 \mathrm{ft}$ $(61 \mathrm{~cm})$ apart. The actuating levers on the microswitches contain metal hooks, which are used to hold one end of 1-in $(2.5 \mathrm{~cm})$ paper computer tapes, the other ends of which are fastened to the top members of the frames with masking tape, also $2.0 \mathrm{ft}(61 \mathrm{~cm})$ apart. The tapes are kept under tension such that any impact on them will close the microswitches and actuate the triggering mechanism to start and stop the counter (5).

The compressed air gun (4) is a commercially available device manufactured by Diamond King, Inc. ${ }^{2}$ (El Segundo, Calif.). It is their Mark 14 model, with a $31 / 4$-in $(8.3 \mathrm{~cm})$ inside diameter barrel and a maximum muzzle velocity of $300 \mathrm{ft} / \mathrm{s}(9144 \mathrm{~cm} / \mathrm{s})$. The counter is a Hewlett-Packard Model No. 523B microsecond counter, with both starting and stopping gates and a direct readout.

\subsection{Hailstone Carriers}

The hail carriers were made from 3-in (7.6 cm) diameter foamed polyethylene cylinders (Ethafoam-Dow Chemical Co., Midland, Mich.). This material was obtained as cylinders $9 \mathrm{ft}(274 \mathrm{~cm})$ long, sliced into short cylinders 6-in $(15.2 \mathrm{~cm})$ long and split in half longitudi- 


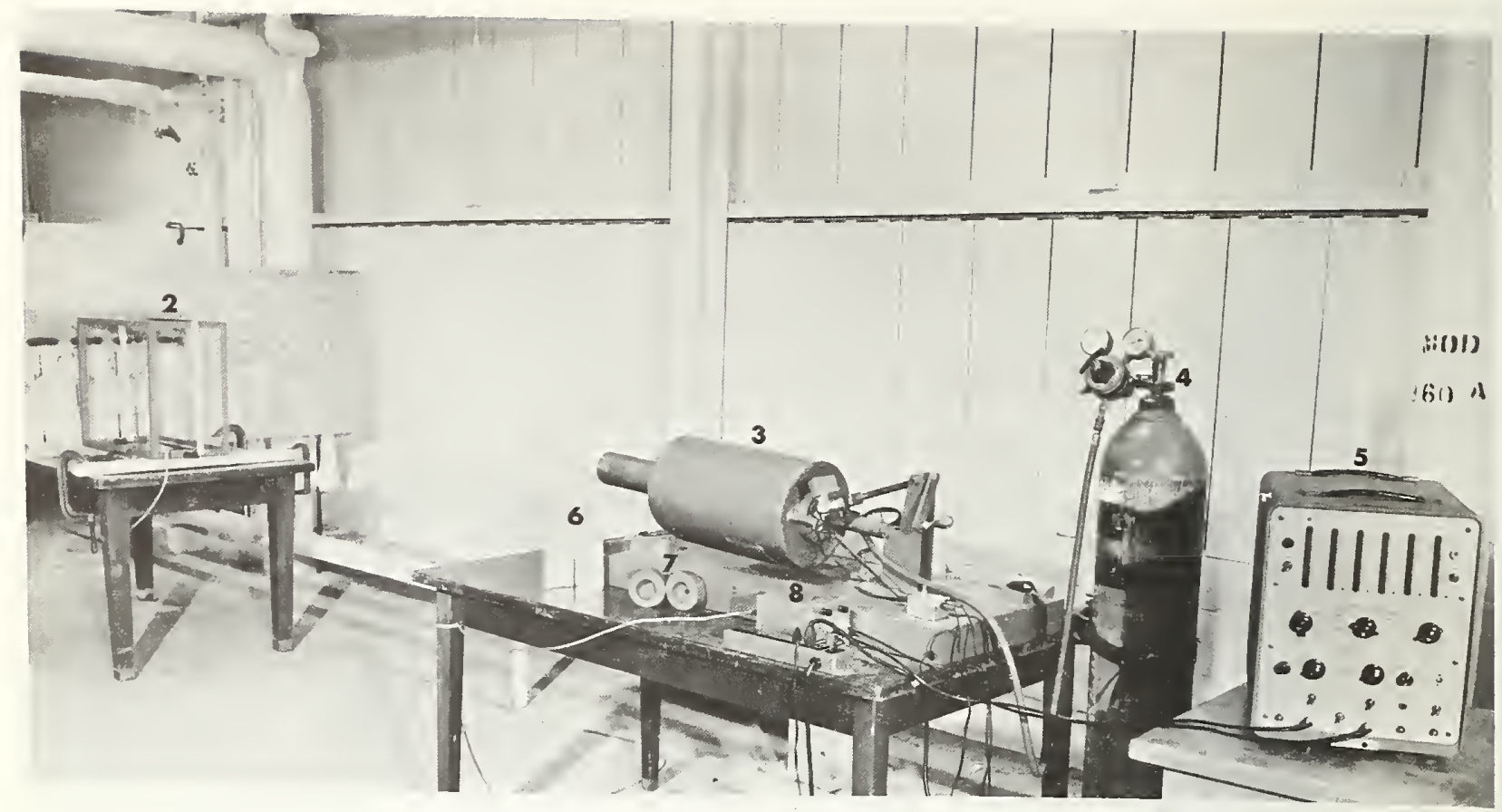
The hail resistance of building materials until failure occurred.
1. Test specimen.
2. Timing section.
3. Compressed gas gun.
4. Gas cylinder.
5. Timer.
6. Hailstone carriers-one in gun and one in open to show cavity.
7. Hailstone mold
8. Triggering mechanism.

FIGURE 2. Hail resistance apparatus.

nally (Item 6 fig. 2). Each hemicylinder was truncated at one end at $45 \mathrm{deg}$ to its long axis from the central cut to its outer wall and milled with one of a series of sizes of hemispheres centered $21 / 4$ in $(5.7 \mathrm{~cm})$ from its other end. Thus, when the two hemicylinders were reassembled, they formed carriers for the several sizes of hailstones and permitted one size barrel to be used for all of the hailstones. Carriers with recesses for $11 / 2(3.8 \mathrm{~cm}), 2(5.1 \mathrm{~cm})$, $21 / 2(6.4 \mathrm{~cm})$ and $23 / 4$ in $(7.0 \mathrm{~cm})$ hailstones were made. The $11 / 4$-in $(3.2 \mathrm{~cm})$ hailstones were carried in the $11 / 2$-in $(3.8 \mathrm{~cm})$ carrier and the $13 / 4$-in $(4.5 \mathrm{~cm})$ hailstones, in the 2-in $(5.1 \mathrm{~cm})$ carrier.

\subsection{Hailstone Molds}

The hailstones were cast in molds made from a silicone casting resin (RTV-60-General Electric Co.). The models for the hailstones were plastic fishing floats, which are produced in increments of $1 / 4$-in $(0.6 \mathrm{~cm})$ diameter from 1-in $(2.5 \mathrm{~cm})$ to 3 -in $(7.6 \mathrm{~cm})$. Each float was suspended on the end of a rod, which fit the indentation in the float, in the center of a cylindrical polyethylene container of suitable size. The casting resin was deaerated, poured into the mold and cured. The following day the casting was removed from the polyethylene con- tainer and sliced through with a razor blade at a great circle of the float. The float and rod were removed and the cut interface covered with a thin layer of silicone grease.

The hailstones were cast in these molds in two stages, in order to permit expansion of water during freezing to occur without shattering the hailstones. Water was poured into the mold through the opening (called the gate) left by the removal of the suspending rod until the cavity (left by the float) was about one-half full and frozen in the freezing compartment of a conventional refrigerator. Four hours later water was added to fill the mold just to the bottom of the gate and the mold was returned to the freezer. Only by this twostage process was it possible to freeze ice

\subsection{Specimen Construction}

The shingle specimens were applied with four staples (per strip) to $1 \mathrm{ft} 6$ in $\mathrm{x} 3 \mathrm{ft} 0$ in (46 x spheres without shattering. While the structure of these synthetic hailstones is different from that of naturally formed hailstones, it was felt that the differences in structure did not affect their performance.

\footnotetext{
2 References to specific articles in the description of apparatus used in these experiments are for the purpose of definition of the experimental details, and should not be construed as preferential endorsements of these articles.
} 
The ice spheres were stored in a chest-type freezer at about $10^{\circ} \mathrm{F}\left(-12^{\circ} \mathrm{C}\right)$ until ready for use.

$91 \mathrm{~cm}$ ) decks, representative of those used in construction $(3 / 8$ in $(1 \mathrm{~cm})$ and $1 / 2$ in $(1.3 \mathrm{~cm})$ plywood, 1 in $x 6$ in (nominal) $T \&$ G boards) The decks were supported on 2-2 in $x 4$ in (nominal) "rafters," to which they were fastened 6 in $(15.2 \mathrm{~cm})$ from each of the short sides by $8 \mathrm{~d}$ common nails. Thus, each deck represented a $1 \mathrm{ft} 6$ in $\times 3 \mathrm{ft} 0$ in $(46 \times 91 \mathrm{~cm})$ section out of a conventional roof.
Wood, slate, asbestos cement, tile, and sheet metal roofing were applied as directed by their suppliers to decks supported on 2 in $\mathrm{x} 4$ in rafters, $2 \mathrm{ft}(61 \mathrm{~cm})$ on centers.

The built-up roofing specimens, $1 \mathrm{ft}(30.5 \mathrm{~cm})$ square, were solidly mopped to $1 / 2$ in $(1.3 \mathrm{~cm})$ plywood or 1 in $(2.5 \mathrm{~cm})$ asbestos cement board (to simulate a concrete deck) or to various types of insulation mopped solidly to these decks. Also, where metal decking was used, the insulation was mopped solidly to the decking.

\section{Procedures}

\subsection{Shooting Hailstones at Roofing}

The specimen on its deck was held against the backstop in figure 2 with large $\mathrm{C}$ clamps. The 1-in $(2.5 \mathrm{~cm})$ paper computer tapes were hooked to the microswitches and fastened to the top of the timing frame with masking tape. They were held under tension, just insufficient to close the switches. A hailstone of the desired size was taken from the freezer, cleaned of any burrs or projecting pieces of ice (from the gate in the mold), weighed, and placed in its carrier, which was slid into the barrel of the gun as far as possible. Air, or nitrogen, was permitted to enter the gun until the desired pressure was reached. The valves between the gun and the tank were closed (to protect the pressure regulator), the pressure gage was removed from the gun, and the gun was fired by opening the solenoid valve, which relieved the pressure behind the floating cylinder in the gun and permitted the remainder of the pressurized gas to escape into the barrel and expel the hailstone carrier.

The carrier was propelled out of the gun, where the air resistance opened the two halves and permitted the hailstone to travel alone toward the target. As the hailstone hit the first tape it started the counter, and as it hit the second tape, it stopped the counter. Then it hit the specimen.
The indentation on the specimen was measured and the condition of the specimen noted after each firing. A minimum of two hits in each area of vulnerability was observed and average values of damage used. Granule losses, coating and felt fractures and deck damage were recorded. The average velocities and energies of the hailstones in the $2 \mathrm{ft}(61 \mathrm{~cm})$ of travel immediately in front of the test specimen also were calculated and recorded.

\subsection{Evaluating Failure}

Damage to roofing by hail falls into two general categories: (1) Severe damage, which leads to penetration of the structure by the elements and (2) Superficial damage, which affects appearance but does not materially interfere with the performance of the roofing. While the latter is distracting and leads to insurance claims, the former is the type of damage that should be of most concern, because the possible loss can exceed the replacement cost of the roofing many fold. Thus, while the dents will be reported, only the fractures of the coating, felt or other shingle material will be called failure in this report. For each material and roofing system, the thresholds of failure, or the smallest hail size producing these failures, are reported.

\section{Results}

Although hailstones vary in size, shape, density, and velocity, those that do damage to buildings tend to fall within the narrow limits of ice spheres falling at about their free-fall terminal velocity $[9]$.

The density of large hailstones has been shown to approximate that of solid ice [10] and seems to range between 0.89 and 0.91 $\mathrm{g} / \mathrm{cm}^{3}$. Hailstones, while rarely smooth spheres, can be treated aerodynamically as smooth spheres and conclusions reached are close to observed results [11]. The terminal velocities and energies of ice spheres have been calculated and reported graphically by Laurie [9]; they are tabulated below as taken from these graphs for the hailstone sizes used:

TABLE 1. Terminal velocities and energies of hailstones ${ }^{a}$

\begin{tabular}{|c|c|c|c|c|c|c|}
\hline \multicolumn{2}{|c|}{ Diameter } & \multicolumn{3}{|c|}{ Terminal velocity } & \multicolumn{2}{|c|}{$\begin{array}{l}\text { Approximate } \\
\text { impact } \\
\text { energy }\end{array}$} \\
\hline $\begin{array}{l}\text { inches } \\
1 \\
11 / 4 \\
11 / 2 \\
13 / 4 \\
2 \\
21 / 2 \\
23 / 4 \\
3\end{array}$ & $\begin{array}{c}c m \\
(2.5) \\
(3.2) \\
(3.8) \\
(4.5) \\
(5.1) \\
(6.4) \\
(7.0) \\
(7.6)\end{array}$ & $\begin{array}{r}f t / s \\
73 \\
82 \\
90 \\
97 \\
105 \\
117 \\
124 \\
130\end{array}$ & $\begin{array}{c}m i / h r \\
50 \\
56 \\
61 \\
66 \\
72 \\
80 \\
85 \\
88\end{array}$ & $\begin{array}{l}(\mathrm{m} / \mathrm{sec}) \\
(22.3) \\
(25.0) \\
(27.4) \\
(29.6) \\
(32.0) \\
(35.7) \\
(37.8) \\
(39.6)\end{array}$ & $\begin{array}{r}\text { ft lbs } \\
<1 \\
4 \\
8 \\
14 \\
22 \\
53 \\
81 \\
120\end{array}$ & $\begin{array}{c}\text { Joules } \\
(<1.36) \\
(5.42) \\
(10.85) \\
(18.96) \\
(29.80) \\
(71.9) \\
(109.8) \\
(162.7)\end{array}$ \\
\hline
\end{tabular}


All of the results reported are based on hailstones of a given size traveling at velocities within \pm 10 percent of the terminal velocities reported in table 1 for hailstones of that size. The results are reported under the types of roofing studied.

\subsection{Asphalt Shingles}

When applied according to the recommendations of their manufacturers, Type 235 squaretab shingles have three regions of different vulnerability: (1) The tab edges, (2) The surface over the unsupported areas between the top of one strip and the "line" where the strip above it contacts the deck or underlayment, and (3) The triple coverage area solidly supported from the deck up [12].
The resistances of these areas to hail damage are different; therefore, results are reported for each area. The results for the Type 235 square-tab shingles are shown in table 2.

These specimens were also exposed to $11 / 4$-in dentations were made in the shingles by the $(3.2 \mathrm{~cm})$ hailstones. Only small, superficial in$11 / 4$-in $(3.2 \mathrm{~cm})$ hailstones. The larger size hailstones produced progressively larger dents. In general, the smaller hailstones produced circular indentations approximating one half their diameter and the larger hailstones, those above the felt-damage threshold, produced dents greater in diameter than one-half the hailstone diameter. Hailstones $23 / 4$ in $(7.0 \mathrm{~cm})$ in diameter produced damage to the decks on which the shingles were mounted.

TABLE 2. Hail resistance of Type 235 square tab shingles exposed 5 in $(12.7 \mathrm{~cm})$

\begin{tabular}{|c|c|c|c|c|c|c|c|c|c|c|c|c|}
\hline \multirow{3}{*}{ Deck } & \multicolumn{12}{|c|}{ Smallest hail size cracking shingle felt } \\
\hline & \multicolumn{6}{|c|}{ No underlayment } & \multicolumn{6}{|c|}{ 15\# Felt underlayment } \\
\hline & \multicolumn{2}{|c|}{ Edges } & \multicolumn{2}{|c|}{$\begin{array}{l}\text { Unsupported } \\
\text { portion }\end{array}$} & \multicolumn{2}{|c|}{$\begin{array}{l}\text { Triple } \\
\text { coverage }\end{array}$} & \multicolumn{2}{|c|}{ Edges } & \multicolumn{2}{|c|}{$\begin{array}{l}\text { Unsupported } \\
\text { portion }\end{array}$} & \multicolumn{2}{|c|}{$\begin{array}{l}\text { Triple } \\
\text { coverage }\end{array}$} \\
\hline $3 / 8$-In Plywood.......... (1 cm) & $i_{13 / 4}$ & $\begin{array}{l}c m \\
(4.5)\end{array}$ & ${ }^{\text {in }}$ & $\begin{array}{l}c m \\
(4.5)\end{array}$ & ${ }_{13}^{i n}$ & $\begin{array}{l}c m \\
(4.5)\end{array}$ & $i_{11 / 2}$ & $\begin{array}{l}c m \\
(3.8)\end{array}$ & $i_{11 / 2}$ & $\begin{array}{l}c m \\
(3.8)\end{array}$ & $i_{13 / 4}$ & $\stackrel{c m}{(4.5)}$ \\
\hline $1 / 2$-in Plywood........ $(1.3 \mathrm{~cm})$ & $13 / 4$ & $(4.5)$ & $13 / 4$ & $(4.5)$ & $13 / 4$ & $(4.5)$ & $11 / 2$ & $(3.8)$ & $11 / 2$ & $(3.8)$ & $11 / 2$ & (3.8) \\
\hline $1 \times 6$ in & 2 & $(5.1)$ & $13 / 4$ & $(4.5)$ & $21 / 2$ & (6.4) & $11 / 2$ & $(3.8)$ & $11 / 2$ & $(3.8)$ & 2 & (5.1) \\
\hline
\end{tabular}

Shingles on $3 / 8$-in $(1 \mathrm{~cm})$ and $1 / 2$-in $(1.3 \mathrm{~cm})$ plywood performed equally well; those on $1 \mathrm{x}$ 6 -in $\mathrm{T} \& \mathrm{G}$ roof boards were more resistant to hail damage than those on plywood.

The shingles without an underlayment consistently had a higher threshold of hail damage than did those with the conventional $15 \mathrm{lb}$ saturated felt underlayment on all three decks. Apparently, the soft layer of felt makes the shingle slightly more vulnerable. The improved performance usually involved only $1 / 4$-in $(0.6$ $\mathrm{cm})$ larger hailstones, but this represented resistance to 6.3 or 9.5 more foot pounds ( 8.5 or 12.8 joules) of kinetic energy. From these results, it would seem that the solidly supported roofings performed better than those with some soft underlying layer in their construction. This observation is consistent with the fact that shingle materials are stronger in compression than in tension and the best performance can be expected when the impact forces can be kept as pure compression forces. Any soft layer within the system permits the back of the layer above it to be in tension and fail more easily.

As shingles age during exposure they tend to undergo a number of physical changes, which may affect their resistance to hail. A number of shingles that had been exposed on $1 / 2$-in $(1.3$ $\mathrm{cm})$ plywood to the weather in Washington, D. C. for $91 / 2$ years became available and were tested. These shingles had been exposed at a 4-in pitch $(10 \mathrm{~cm}$ in $30 \mathrm{~cm})$ facing due south. Three different Type 210 shingles showed failures (felt cracking) on all three areas of different vulnerability with $11 / 4$-in $(3.2 \mathrm{~cm})$ hailstones. One Type 255 and one Type 290 shingle experienced spalling of the coating with $11 / 4$-in $(3.2 \mathrm{~cm})$ hailstones, but felt damage did not occur until 11/2-in $(3.8 \mathrm{~cm})$ hailstones were used. Two Type 250 shingles showed felt damage in all three areas of vulnerability with $11 / 4$ in $(3.2 \mathrm{~cm})$ hailstones; however, one Type 250 and one Type 275 shingle showed no damage below $13 / 4$-in $(4.5 \mathrm{~cm})$ hailstones on the tab centers, but both developed felt damage in the other two areas with $11 / 4$-in $(3.2 \mathrm{~cm})$ hailstones. No direct comparison can be made between these aged shingles and unexposed ones because of changes in design and production. However, the aged shingles tended to be less resistant to hail damage than the new ones.

A number of heavy weight and premium shingles were also investigated. Some of these resisted hail no better than the regulai Type 235 square-tab shingles. However, a few performed significantly better, as discussed below.

A Class B shingle based on a glass fiber mat, instead of the conventional organic felt, did not show felt-type failure on its tab edges and unsupported areas with hailstones smaller than $2 \mathrm{in}(5.1 \mathrm{~cm})$. It failed with $2 \frac{1}{2}$-in $(6.4 \mathrm{~cm})$ 
hailstones on the solidly supported areas. Similarly, three other shingles, all Class A, based on glass mat felts showed no felt damage on their obverse sides with hailstones below 2 in $(5.1 \mathrm{~cm})$ in diameter; one of these had a damage threshold at the $21 / 2$-in $(6.4 \mathrm{~cm})$ hailstone on all three portions of its surface. Some of the conventionally made heavy shingles, usually with Number 9 granules or with high concentrations of mineral additives, performed equally well. One Type 290 Class C shingle actually had a damage threshold at the $23 / 4$-in $(7.0 \mathrm{~cm})$ hailstone. While it is outside the province of this report to identify these heavy Class $C$ and Class A shingles more specifically, the manufacturers have been informed of how their individual products performed and the basic principles required to make more hail-resistant products. All of these shingles were mounted on $1 / 2$-in $(1.3 \mathrm{~cm})$ plywood.

Because the vast majority of hailstorms occur in warm weather, the roofs are above ambient temperatures when the hailstorm starts. Hailstorms that produce large hailstones are always of short duration and are preceded by a cloud cover, which drops the roof temperatures below their daily highs. Therefore, the hail resistance evaluation was conducted at 75 to $80^{\circ} \mathrm{F}\left(24\right.$ to $\left.27^{\circ} \mathrm{C}\right)$. However, one Type 235 and one Type 315 Class $\mathrm{C}$ shingle and one Type 240 Class A shingle were tested at $120^{\circ} \mathrm{F}$ $\left(49^{\circ} \mathrm{C}\right)$. on a $1 / 2$-in $(1.3 \mathrm{~cm})$ plywood deck with a $15 \mathrm{lb}$ saturated felt underlayment. The hail resistance of the Type 235 shingle was increased to the $21 / 2$-in $(6.4 \mathrm{~cm})$ hailstones from the $11 / 2$-in $(3.8 \mathrm{~cm})$ hailstones on all three surfaces. That of the Type 315 shingle was improved only on the unsupported areas and that of the Type 240 was not changed. Thus, the results on these three shingles indicate that shingles tend to be more resistant to hail damage at higher temperatures. It is fortunate that hailstorms occur in warm weather.

\subsection{Built-Up Roofs}

Occasionally in residential construction and much more frequently in commercial and industrial construction relatively flat roofs are used. These roofs are not "factory manufactured," but "built up" on the site from alternate layers of bitumen and reinforcing membranes. Some of these roofs are surfaced with a smooth layer of bitumen and others are surfaced with a layer of pebbles, crushed stone or light weight aggregate particles in addition to a layer of bitumen. There are many variations of this type of roof system; only a few representative ones were tested. The construction of these roofs and the results of the hail-resistance tests are summarized in table 3 .
The conventional smooth-surface built-up roof [1a and 1e in table 3] on a dense deck showed visible signs of damage; i.e., cracking of the surface, when 2-in $(5.1 \mathrm{~cm})$ hailstones were used. Smaller hailstones usually indented the flood coat, but did not crack it. When fiberboard (1b) or glass fiber (1g) insulation was installed between the deck and the roof membrane the indentations were larger and coating cracks appeared with $13 / 4$-in $(4.5 \mathrm{~cm})$ hailstones. The roofing on Foamboard A insulation (1c) performed better than on the dense decks when 2-in $(5.1 \mathrm{~cm})$ hailstones were used, but $21 / 2$-in $(6.4 \mathrm{~cm})$ hailstones penetrated through the roofing into the insulation. Foamboard B (1d) delaminated; i.e., the insulation broke away from its protective asphalt coated felts, when impacted with 2-in $(5.1 \mathrm{~cm})$ hailstones. The roofing on glass fiber insulation (1g) on steel decking was penetrated by $21 / 2$-in $(6.4 \mathrm{~cm})$ hailstones.

The flood coat of the built-up roof made with asbestos felts on a plywood deck (2a) did not crack or become indented by $21 / 2$-in $(6.4 \mathrm{~cm})$ hailstones; however, the flood coat was indented and cracked by 2-in $(5.1 \mathrm{~cm})$ hailstones when fiberboard insulation (2c) was used between the membrane and the deck. The asbestos-felt roofs had better hail resistance than the rag felt built-up roofs on comparable decks.

The built-up roofs made with coal tar pitch [3], referred to as tar in table 3, did not indent, but developed concentric cracks with all sizes of hailstones. The $21 / 2$-in $(6.4 \mathrm{~cm})$ hailstones caused some of the flood coat to spall from the top felts [3a]. Coal tar pitch generally tends to be more brittle than asphalt and would be expected to respond to the hail impact as a brittle material.

The roofs built up with glass fiber felts on the dense decks (4a and 4b) (plywood and asbestos cement) did not experience flood coat cracking with hailstones $21 / 2$-in $(6.4 \mathrm{~cm})$ in diameter and smaller, but when insulation was present (4c. 4d, 4e, and 4f), cracks were produced with $21 / 2$-in $(6.4 \mathrm{~cm})$ hailstones. The glass felt roofs fell in between the organic felt builtup roofs and asbestos felt built-up roofs in hail resistance.

The roofs constructed of two base sheets (5) performed much better on the asbestos cement deck (5b) than on plywood (5a); their performance on plywood or insulation were about the same as conventional asphalt-organic-felt built-up roofs on the same substrates. Where these roofs were covered with $300 \mathrm{lbs} / \mathrm{sq}$ of slag $\left(14.7 \mathrm{~kg} / \mathrm{m}^{2}\right)(6)$, no damage was done to the roof membrane by any of the hailstones. (The slag was retained by cheese cloth when the decks were tested in vertical positions). The hailstone energy was dissipated in scattering 


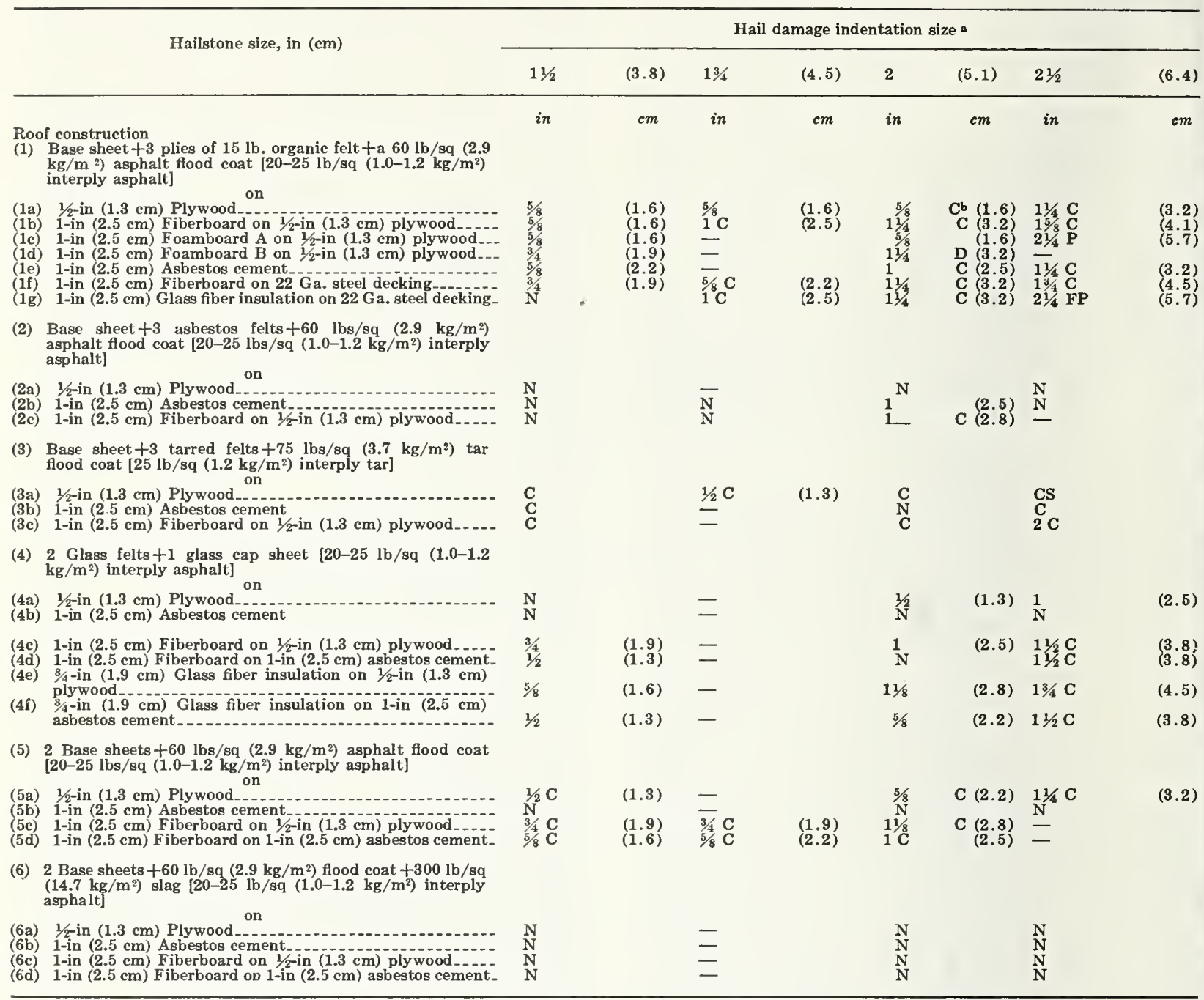

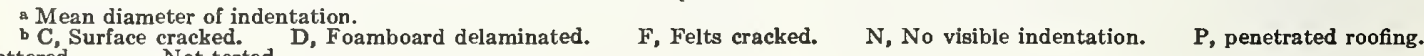

S, Coating shattered. $\quad$, Not tested.

the slag; "nests" of various sizes were left in the slag.

In summary, each roofing membrane performed better on the denser substrates than on the lighter substrates, the roofings made with inorganic felts performed better than those made with organic felts and the slag surfaced roofing was not damaged by hailstones up to and including $21 / 2$-in $(6.4 \mathrm{~cm})$ in diameter.

\subsection{Nonbituminous Roofing}

A number of nonbituminous roofings were tested for comparison purposes. These were applied in accordance with their supplier's recommendations. The levels of failure used in these evaluations were cracking for brittle roofings and objectionable indentations for metal roofing. Table 4 is a summary of the results of these tests. 


\begin{tabular}{|c|c|c|c|c|c|c|}
\hline \multirow{2}{*}{ Description } & \multicolumn{6}{|c|}{ Diameter of smallest hailstone causing damage } \\
\hline & \multicolumn{2}{|c|}{ Edge } & \multicolumn{2}{|c|}{ Center } & \multicolumn{2}{|c|}{ Unsupported } \\
\hline 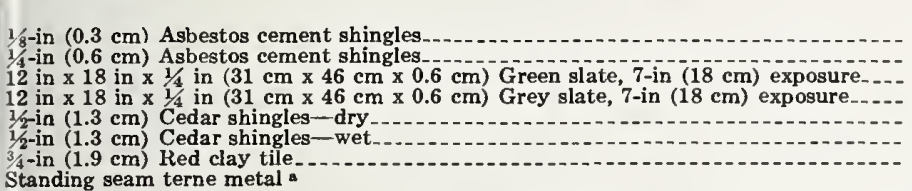 & $\begin{array}{l}\text { in } \\
11 / 2 \\
2 \\
13 / 4 \\
- \\
-\end{array}$ & $\begin{array}{c}c m \\
(3.8) \\
(5.1) \\
(4.5)\end{array}$ & $\begin{array}{l}\text { in } \\
13 / 4 \\
2 \\
2 \\
2 \\
11 / 2 \\
11 / 2 \\
2\end{array}$ & $\begin{array}{l}\mathrm{cm} \\
(4.5) \\
(5.1) \\
(5.1) \\
(5.1) \\
(3.8) \\
(3.8) \\
(5.1)\end{array}$ & $\begin{array}{l}\frac{i n}{13 / 4} \\
13 / 4 \\
11 / 2 \\
13 / 4 \\
11 / 2 \\
18 / 4\end{array}$ & $\begin{array}{c}\mathrm{cm} \\
(4.5) \\
(4.5) \\
(5.1) \\
(3.8) \\
(4.5) \\
(3.8) \\
(4.5)\end{array}$ \\
\hline
\end{tabular}

- Dents proportional to hail size-visible for all hailstone sizes. The plywood deck cracked below the dents with hailstones larger than $21 / 2$ in (6.4 em). - Note tested.

All roofings tested were vulnerable to hail damage. As with the asphalt shingles, these other products contained areas of difierent vulnerability.

\section{Conclusions}

(a) All roofing materials have some resistance to hail damage, but as the size of the hail increases, a level of impact energy is reached at which damage occurs. This level lies in the area of $11 / 2$ to 2 -in $(3.8-5.1 \mathrm{~cm})$ stones for most prepared roofings.

(b) Because of the ways in which prepared roofings are applied, most products have areas of different vulnerability.

(c) Heavier shingles tend to be more hailresistance than Type 235 shingles.

(d) Weathering tends to lower the hail resistance of asphalt shingles.

(e) The solidly supported areas of roofing tend to be the most resistant to hail damage.

(f) Built-up roofs on hard substrates tend to resist hail better than those on soft substrates.

(g) Built-up roofs made with inorganic felts tend to be more hail resistant than those made with organic felts.

(h) Coarse aggregate surfacing tends to increase the hail resistance of roofing. (i) The slate, asbestos cement and tile roofings tested contained areas of different vulnerability and cracked under the impact of $11 / 2$ - to 2 -in $(3.8-5.1 \mathrm{~cm})$ hailstones.

(j) The sheet metal roofing was dented by all sizes of hailstones used. Deck cracking occurred when $21 / 2$-in $(6.4 \mathrm{~cm})$ hailstones were used.

This work was sponsored by the Research Committee of the Asphalt Roofing Manufacturers Association, under the Research Associate Plan, at the National Bureau of Standards. The author wishes to thank Royce Stine and Thomas Crowe for their help in constructing the apparatus and collecting the data upon which this article is based. He also thanks the Materials Durability and Analvsis Section, and particularly its Chief, W. C. Cullen, for their help and encouragement that made this work possible.

\section{References}

[1] Storm Data, Environmental Science Services Administration, U.S. Department of Commerce, Asheville, N.C.

[2] Douglas, R. H., Recent hail research: A review, Meteorol. Monographs 5, 157-167 (1963).

[3] Werckmann, H., The Language of Hailstorms and Hailstones, ÚSASRDL Rep. 2277, U.S. Army Research \& Development Laboratory, Ft. Monmouth, N.J. (1962).

[4] Schleusener, R. A., Hailstorm characterization and the crystal structure of hail, Meteorol. Monographs 5, 173-176 (1963).

[5] Texas Hailstorms, Texas State Board of Insurance, Austin, Texas.

[6] Schumann, T. E., The theory of hailstone formation, Quart. J. Roy. Meteorol. Soc. 64, 3-4 (1938).

[7] Flora, S. D., The Serious Toll of Hail Storms, Rough Notes 82, 14, 1939.
[8] Fuchs, E. R., Hailstorm, American Roofer 10 (Nov. 1955).

[9] Laurie, J. A. P., Hail and Its Effects on Buildings, C.S.I.R. Research Report No. 176, Bull. 21, 1-12, National Building Research Institute, Pretoria, South Africa (1960).

[10] Browning, K. A., F. H. Ludlam, and W. C. Lacklin, The density and structure of hailstones, Quart. J. R. Meteorol. Soc. 89, 75-84 (1963) Roy. meteorol.

[11] Bilham, E. G., and E. F. Relf, The dynamics of large hailstones, Quart. J. Roy Meteorol. Soc. 63, 149-162 (1937).

[12] Manufacture, Selection and Application of Asphalt Roofing and Siding Products,. Ninth edition, 1966, Asphalt Roofing Industry Bureau, New York, N.Y. 



\section{Announcement of New Publications in Building Science Series}

Superintendent of Documents, Government Printing Office,

Washington, D.C., 20402

\section{Dear Sir:}

Please add my name to the announcement list of new publications to be issued in the series: National Bureau of Standards Building Science Series.

Name

Company

Address

City

State

Zip Code

(Notification key $\mathrm{N}-339$ ) 


\section{NATIONAL BUREAU OF STANDARDS}

The National Bureau of Standards ' was established by an act of Congress March 3, 1901. Today, in addition to serving as the Nation's central measurement laboratory, the Bureau is a principal focal point in the Federal Government for assuring maximum application of the physical and engineering sciences to the advancement of technology in industry and commerce. To this end the Bureau conducts research and provides central national services in four broad program areas. These are: (1) basic measurements and standards, (2) materials measurements and standards, (3) technological measurements and standards, and (4) transfer of technology.

The Bureau comprises the Institute for Basic Standards, the Institute for Materials Research, the Institute for Applied Technology, the Center for Radiation Research, the Center for Computer Sciences and Technology, and the Office for Information Programs.

THE INSTITUTE FOR BASIC STANDARDS provides the central basis within the United States of a complete and consistent system of physical measurement; coordinates that system with measurement systems of other nations; and furnishes essential services leading to accurate and uniform physical measurements throughout the Nation's scientific community, industry, and commerce. The Institute consists of an Office of Measurement Services and the following technical divisions:

Applied Mathematics-Electricity-Metrology-Mechanics-Heat-Atomic and Molecular Physics-Radio Physics -2Radio Engineering "-Time and Frequency - Astron'ıysics "-Cryogenics. ${ }^{2}$

THE INSTITUTE FOR MATERIALS RESEARCH conducts materials research leading to improved methods of measurement standards, and data on the properties of well-characterized materials needed by industry, commerce, educational institutions, and Government; develops, produces, and distributes standard reference materials; relates the physical and chemical properties of materials to their behavior and their interaction with their environments; and provides advisory and research services to other Government agencies. The Institute consists of an Office of Standard Reference Materials and the following divisions:

Analytical Chemistry-Polymers-Metallurgy-Inorganic Materials-Physical Chemistry. THE INSTITUTE FOR APPLIED TECHNOLOGY provides technical services to promote the use of available technology and to facilitate technological innovation in industry and Government; cooperates with public and private organizations in the development of technological standards, and test methodologies; and provides advisory and research services for Federal, state, and local government agencies. The Institute consists of the following technical divisions and offices:

Engineering Standards-Weights and Measures - Invention and Innovation - Vehicle Systems Research-Product Evaluation-Building Research-Instrument Shops-Measurement Engineering-Electronic Technology-Technical Analysis.

THE CENTER FOR RADIATION RESEARCH engages' in research, measurement, and application of radiation to the solution of Bureau mission problems and the problems of other agencies and institutions. The Center consists of the following divisions:

Reactor Radiation-Linac Radiation-Nuclear Radiation-Applied Radiation.

THE CENTER FOR COMPUTER SCIENCES AND TECHNOLOGY conducts research and provides technical services designed to aid Government agencies in the selection, acquisition, and effective use of automatic data processing equipment; and serves as the principal focus for the development of Federal standards for automatic data processing equipment, techniques, and computer languages. The Center consists of the following offices and divisions:

Information Processing Standards-Computer Information - Computer Services - Systems Development-Information Processing Technology.

THE OFFICE FOR INFORMATION PROGRAMS promotes optimum dissemination and accessibility of scientific information generated within NBS and other agencies of the Federal government; promotes the development of the National Standard Reference Data System and a system of information analysis centers dealing with the broader aspects of the National Measurement System, and provides appropriate services to ensure that the NBS staff has optimum accessibility to the scientific information of the world. The Office consists of the following organizational units:

Office of Standard Reference Data-Clearinghouse for Federal Scientific and Technical Information "-Office of Technical Information and Publications-Library-Office of Public Information-Office of International Relations.

1 Headquarters and Laboratories at Gaithersburg, Maryland, unless otherwise noted: mailing address Washington, D.C. 20234

2 Lacated at Boulder. Colorado 80302.

${ }^{3}$ Located at 5285 Port Royal Rosd, Springfield, Virginia 22151 
